\title{
DESNECESSIDADE DA PRESENÇA DO JUIZ AO ATO DE ARREMATAÇĀO, NO SISTEMA DO CÓDIGO DE PROCESSO CIVIL *
}

\author{
EDSON RIBAS MALACHINI * *
}

SUMÅRIO: 1. O problema. - 2. A posição dos processualistas. - 3. Sentido histórico e evolução do instituto. - 4. Análise dos dispositivos pertinentes, do Código de Processo Civil, à luz da realidade -5 . Conclusão.

1. O juiz preside a praça, realizada no átrio do fórum, ou mesmo o leilão, realizado "onde estiverem os bens, ou no lugar designado pelo juiz" (Cód. de Proc. Civil, art. 686, § 20., e art. 705, II)?

A maioria dos processualistas brasileiros, ao tratar do procedimento da arrematação, já à luz do Código de Processo Civil de 1973, tem-se omitido de examinar esse ponto.

PEREIRA E SOUZA, nas Primeiras Linhas, ${ }^{1}$ escreveu:

"São requisitos da arrematação: I - Que se faça por ordem judicial; II - Que seja presidida pelo juiz; III - Que se faça a quem oferecer maior preço, contanto que cubra o da avaliação; IV Que se faça com dinheiro à vista, ou sob de fiança idônea para pagar em três dias, e não a crédito". $E$, em nota, fazia remissão à Ordenação, Livro III, Título 86, § 27, ao Decreto de 24 de abril de 1709 e à Lei de 20 dejunho de 1774, § 13, acrescentando: "Sem isso a arrematação é nula" (nota 793).

A Ordenação, no parágrafo indicado ( $\$ 27$ do Tít. 86 do Liv. III), dizia apenas: ". . . A qual arrematação se fará sempre por mandado do Julgador, que mandou fazer a penhora e execução. . . .."2

- Estado destinado ao número especial da Revista de Processo, (ed. Rev. dos Tribs.), em homenagem ao Prof. ALFREDO BUZAID.

- Juiz de Direito em Curitiba e Professor Assistente de Direito Processual Civil na Universidade Federal do Paraná. 
Já o Regulamento 737 era expresso: “Art. 548. A arrematação será feita no dia e lugar anunciados, publicamente; presentes o juiz, escrivão, e porteiro, e expostos os objetos que devem ser arrematados, ou as amostras, sendo possível".

Explícito também foi o Código de Processo Civil de 1939, art. 965, caput, quanto à presença do juiz; mas já não o é o Código atual, art. $686, \S 20{ }^{3}$

Presidir (do lat. praesidere) é "dirigir como presidente; exercer funções de presidente em"; é "assistir, dirigindo ou guiando". ${ }^{4}$

Será, pois, que o juiz "dirige" a arrematação, na praça ou leilão - ou quem o faz é o porteiro ou o leiloeiro?

Como dissemos, a pergunta não tem sido respondida de modo satisfatório, a nosso ver. Os poucos autores que se referem especificamente ao ponto, limitam-se a afirmar que a presença do juiz ao ato de arrematação é necessária, sem indicar o fundamento dessa afirmação. Fazem-no como se estivéssemos ainda sob a regra do aludido art. 965 do Código de 1939; como se nenhuma alteração, no particular, tivesse sido trazida pelo Código de 1973. $E$, no entanto, parece-nos que este Código, nesse assunto, inovou.

2. Vejamos, sumariamente, a posição de alguns processualistas, que trataram da execução e particularmente da arrematação.

AMILCAR DE CASTRO, ${ }^{5}$ HUMBERTO THEODORO JÜNIOR, ${ }^{6}$ WILLARD DE CASTRO VILLAR, ${ }^{7}$ e SÁLVIO DE FI. GUEIREDO TEIXEIRA ${ }^{8}$ não fazem referência expressa à presença do juiz ao ato da arrematação.

FREDERICO MARQUES, escrevendo ao tempo da vigência do Código de 1939, e com base no referido art. 965, caput, ${ }^{9}$ afirmava: "Sem a presença do juiz, é óbvio que a praça não pode ser realizada, o mesmo sucedendo quando ausente o escrivão, que é quem subscreve o auto de arrematação. 0 porteiro, embora ausente, pode ser substituído por um ad hoc, por designação do juiz". ${ }^{10}$ Em outro passo observava que "os pregões e a praça se encerram quando o juiz tenha por efetuada a arrematação em favor de quem mais der"; ${ }^{11}$ e em outro: "A assinatura do auto deve ocorrer tão logo se encerre a arrematação, pois o juiz, o escriväo e o porteiro devem estar presentes ao ato, consoante determina o art. 965. E também o arrematante, como é óbvio". ${ }^{12}$

Já no Manual de Direito Processual Civil, escrito sob o regime do Código de 1973, não faz nenhuma referência expressa à presença do juiz no local de realização da praça ou do leilão, limitando-se a dizer, tratando da praça: "Se o juiz, portanto, de ofício ou a pedido de qualquer das partes, certifica-se de que 
efetivamente a arrematação já se mostra suficiente para a solução do pagamento global da execução, cumpre-lhe sustá-la"; ${ }^{13}$ e, mais adiante: "Os pregões e a praça se encerram quando o juiz tenha por efetuada a arrematação, em favor do que ofereceu maior lanço, o qual, na primeira praça, deve superar o preço da avaliação". ${ }^{14}$

CELSO NEVES, falando sobre a "transferência de praça ou leilão", em comentário ao art. 688, escreve: "Motivo justo é, $v$. $g$., a ausência do juiz, desde que se trata de um ato processual por ele determinado e presidido". ${ }^{15}$

E JOSÉ AFONSO DA SILVA, sem incorrer no engano de confundir a segunda praça com o leilão, mas advertindo, ao contrário, para a alteração do sistema do Código, ${ }^{16}$ diz por sua vez que "a praça é ato público que se realiza sob a presidência do juiz, com a presença do escrivão, do porteiro (ou do oficial de justiça, que o substitua) e do depositário dos bens". ${ }^{17}$ Já com referência ao leilão, diz apenas: "O leilão realiza-se por leiloeiro público (onde houver), escolhido livremente pelo credor (art. 706), ao qual" incumbem as providências arroladas no art. $705 .^{18}$

JOSÉ DE MOURA ROCHA escreve: "O art. 688 atinge, quanto à determinação de responsabilidade do juiz, e outros cuja presença se faça necessária à realização da praça ou leilão". ${ }^{19}$ Depois, falando sobre o desfazimento da arrematação "por vício de nulidade" (art. 694, parág. único, 1), diz que "são insanáveis: . . . . A incompetência ratione materiae, se nos referimos ao juiz; a ausência do juiz ou do escrivão, ou do porteiro, etc., etc." $;{ }^{20}$ conquanto adiante, falando especificamente sobre o leilão, diga apenas, a esse respeito: "Pelo no. II" (do art. 705), "cumpre ao leiloeiro realizar o leilão. Será no local onde se encontrem os bens, ou onde for designado pelo juiz. Cumpre salientar a necessidade de precisar-se, além do local, o dia e a hora em que se realizará o leilão lembrando que todos são essenciais. . . . ."'21

JOSÉ DA SILVA PACHECO, a seu turno, anota: "A arrematação far-se-á em dia, hora e lugar anunciados pelos editais, com a presença do juiz, do escrivão e do porteiro dos auditórios". "A presença do juiz é indispensável. Ato importante da execução, deve ser presidido pelo juiz, que não se pode eximir de comparecer. Juiz é diretor do processo, não só no sentido de despachar petições e proferir decisões, mas também no sentido de presidir atos e diligências que se fizerem neces- 
sários". "Pode-se anular arrematação que se fez sem a presença do juiz". ${ }^{22}$

Contudo . . . a impressão que se tem é a de que tal anotação foi feita com vistas ao Código de 1939 (especialmente ao referido art. 965, que mencionava expressamente a "presença do juiz"). ${ }^{23}$ Tal impressão é reforçada pelo fato de que em passagem posterior, ao comentar sobre a "transferência da praça ou leilão", e sobre a "desconstituição do auto de arrematação" - já agora, sim, claramente com vistas ao Código de 1973, arts. 688 e 694, respectivamente - , não faz nenhuma referência à ausência do juiz ao ato de licitação, quer para atribuir-lhe responsabilidade quer para indicar nulidade, decorrente dessa ausência. ${ }^{24}$

MOACYR AMARAL SANTOS, após ter dito, ao falar sobre as "modalidades de arrematação":25 "Dentre as pessoas presentes à praça deverá estar, necessariamente, o porteiro dos auditórios, que é funcionário da justiça, a quem cabe apregoar os bens sujeitos à arrematação e receber os respectivos lanços dos licitantes"; "O leiloeiro público, que é quem no leilão apregoa os bens e recebe os lanços dos licitantes, e cuja presença se faz, assim, indispensável à realização do leilão, 'será livremente escoIhido pelo credor' (Cód. Proc. Civil, artigo 706), dentre os existentes na comarca. . . . ."26 - ressaltando aí, portanto, apenas a necessidade da presença do porteiro ou do leiloeiro, que são os agentes que realizam a hasta pública - , afirma adiante, no entanto, ao discorrer sobre as "formalidades da arrematação": "Terá lugar a arrematação no dia, hora e lugar anunciados no edital, com a presença do juiz, do escrivão e, quando em praça, do porteiro dos auditórios, ou, quando em leilão, do leiloeiro público e do depositário. A presença do juiz e do escrivão se explica porque àquele cabe presidir 0 ato e a este lavrar os termos necessários e ter fiel conhecimento da arrematação, cujo auto subscreverá. Os trabalhos materiais da arrematação em praça são exercidos pelo porteiro dos auditórios e da arrematação em leilão pelo leiloeiro público". ${ }^{27}$

Já depois, todavia, ao tratar do "desfazimento da arrematação" (art. 694, parág. único), não menciona a ausência do juiz entre os exemplos de desfazimentos "por vício de nulidade" (inc. 1). ${ }^{28}$

Finalmente, PONTES DE MIRANDA, ao cuidar dos embargos à arrematação e à adjudicação, e especificamente das "nulidades da arrematação", escreve: "A arrematação pode ser atingida por nulidades sanáveis e insanáveis. São insanáveis, por exemplo, 
se houve falta dos pressupostos processuais (formais) da execução, v. g., se não houve a citação do executado, tal como ocorre, quanto aos processos de cognição no de execução. As nulidades formais da arrematação, inclusive dos editais, são de deduzir-se nos embargos do devedor (arts. 741 e 746). Arrematação sem presença do juiz, ou do escrivão, ou do porteiro, é nula, e essa nulidade é alegável nos embargos do devedor. Se arrematou o bem alguém que não podia lançar, é nula a arrematação e deduzível nos embargos do devedor a nulidade. Cf. Código Civil, arts. 1.133 e $1.134^{\prime \prime} .{ }^{29}$

Tal comentário, ao art. 746 do Código de 1973, entretanto, é reprodução do que fora escrito, pelo incomparável Jurista, como comentário ao art. 1.011 do Código de 1939 (com adaptação dos números dos artigos citados). ${ }^{30}$

Também adiante, ao comentar o art. 688, parágrafo único, do Código atual, diz o Mestre: "RESPONSABILIDADE DOS SERVENTUÁRIOS E DEPOSITÁRIOS. - As penalidades do art. 688, parágrafo único, não isentam os serventuários ou depositários da responsabilidade por perdas e danos e da responsabilidade criminal. As penas do art. 688 , parágrafo único, são independentes da culpa dos serventuários ou depositários. Nem pode ser interpretado para se considerarem livres o juiz e outros figurantes, quer de penas disciplinares, quer de condenação a perdas e danos. $O$ Estado responde por seus funcionários". ${ }^{31}$

Mas esse passo reproduz igualmente, ad litteram, ${ }^{32}$ o que se escrevera como comentário ao art. 966 do Código anterior, ${ }^{33}$ em que, como já se frisou, o art. 965, que o antecedia, determinava expressamente que a arrematação far-se-ia "com a presença do juiz". Significativa é, aliás, a referência (feita sem qualquer observação explicativa) ao depositário, incluído no art. 966 do Código de 1939 mas não no art. 688, parágrafo único, do vigente. ${ }^{34}$

A impressão, que nos fica, de que ao se reproduzirem os comentários acima transcritos não se atentou, suficientemente, para a alteração do sistema, introduzida pelo Código de 1973, é reforçada, aqui mais uma vez, por outras anotações, constantes da mesma obra. Assim é que ao analisar o artigo 694, parágrafo único, o mesmo Autor não menciona, entre as causas de "desconstituição de auto de arrematação", a "nulidade" decorrente da ausência do juiz ao ato de licitação. ${ }^{35} \mathrm{E}$, principalmente, mais adiante, ao comentar os arts. 705 a 707, concernentes especificamente ao leilão (e com correspondência apenas parcial com. os arts. 972 e 980 do Código de 1939), limita-se a ano- 
tar: “LEILĀO E LUGAR. - O leiloeiro tem de realizar o leilão no lugar em que estão os bens, ou naquele que o juiz designou (cf. art. 686, § $20 ., 2^{\mathrm{a}}$. parte). Há de constar do edital; e a realização que desobedeça à regra jurídica é nula". ${ }^{36}$ (Fala-se na realização do leilão pelo leiloeiro e em lugar designado pelo juiz, mas não se fala na "presidência" do ato por este, nem em sua presença); "RECEPÇĀO E DEPÓSITO. - Dentro de vinte e quatro horas tem de ser entregue ao leiloeiro e depositada por ele a quantia correspondente ao produto da alienação, isto é, o preço. O juiz é que dá a ordem para o depósito". 37 (Falase em ser atribuição do juiz dar a ordem para o depósito, mas nenhuma palavra sobre sua suposta atribuição de presidir ao leilão); "AUTO DE LEILÃO. - 0 auto de leilão, posto que o não diga o art. 707, tem de ser assinado pelo juiz, pelo escrivão, pelo arrematante e pelo leiloeiro. Leiloeiro público não faz sozinho o auto. . . ."38 (Ainda aqui, mais expressivamente, adverte-se que o auto tem de ser assinado pelo juiz, e que o leiloeiro não o faz sozinho. . . mas não se lembra a suposta necessidade da presença do juiz no ato que o auto documenta).

3. Aproveitemos aqui, antes de darmos seqüência às nossas considerações, a douta lição de PONTES DE MIRANDA: “CONCEITO. - Arrematação, em sentido de movimento processual, é a submissão do bem penhorado ao procedimento da alienação ao público; em sentido de estática processual, é a assinação do bem, que foi posto em hasta pública, ao lançador que ofereceu o maior lanço, - que arrematou, que pôs o remate à hasta pública. $O$ pregoeiro dizia: 'Há quem mais dê? Se não, arremato'. Quer dizer: considerava findo, entregava o ramo, que em alguns países o 'porteiro' tinha à mão. Enquanto se apregoa, não se pode fazer a arrematação (Ordenações Filipinas, Livro III, Título 86, § 17). ${ }^{39}$ Toda arrematação é ato do juiz, pelo menos no seu impulso (mandado de alienação). Historicamente, exigia a presença do juiz. Assim no sistema jurídico brasileiro. . . . .'40

Aí se diz que a arrematação, "historicamente, exigia a presença do juiz"; e "assim no sistema jurídico brasileiro". No comentário anterior (ao Código de 1939), reproduzido, se dizia: "Historicamente, exigia a presença do juiz. Assim no Código". ${ }^{41}$

A alteração do texto decorre da alteração do Código, que não mais menciona a presença do juiz na hasta pública (como já notamos) - e, portanto, não mais a exige (concluímos nós).

Ainda que historicamente a arrematação exigisse a presença do juiz, isso não impede que na evolução do instituto se tenha entendido que chegou o momento em que se pode dispen- 
sar essa presença (como, a nosso ver, entendeu o legislador brasileiro do Código de 1973). A dinâmica da vida social contemporânea teria imposto essa solução.

Tome-se especificamente o caso do leilão, adotado pelo Código para a alienação pública de bens móveis. Resolveu-se, ao que nos parece, atribuir ao leiloeiro tal licitação justamente para facilitar a alienação de tais bens penhorados. Decidiu-se entregar a tarefa a um agente especializado em vendas em pregão público, para que o fizesse usando de sua técnica peculiar, de sua maior capacidade de divulgação (conquanto o edital deva ser publicado da mesma forma que o de praça: arts. 686 , IV e $\$ 2$ \% , e 705 , I, com a nova possibilidade aberta pela Lei $6.851 / 80$ - art. 687 , § 10 ) e comunicação; porque ao local, onde se fazem habitualmente os leilões em geral (e que pode ser designado pelo juiz para o ato: art. 686 , IV e $\S 2$ 9 , e 705, II), costumam acorrer as pessoas interessadas em adquirir bens por essa forma; etc. ${ }^{42}$

Só esse tipo de considerações, ao que pensamos, explica a alteração do sistema tradicional, feita pelo Código de 1973, atribuindo a alienação dos bens móveis, já na primeira hasta pública (quando há o piso da avaliação), ao leiloeiro. ${ }^{43}$

Tal tendência evolutiva se revela igualmente na recente Lei 6.830, de 22 de setembro de 1980 (Lei de Execução Fiscal), segundo a qual "a alienação de quaisquer bens penhorados será feita em leilão público, no lugar designado pelo juiz" (art. 23, caput) ${ }^{44}$

Ora, tal objetivo, de facilitação e dinamização das licitações judiciais, estaria frustrado se se exigisse a presidência do leilão pelo juiz; ou sua presença nele. Vale repetir a pergunta: Por que, enão, estabelecer-se o leilão, já na primeira arrematação, para os bens móveis? Por que permitir-se que ele se realize "onde se encor:trem os bens, ou no lugar designado pelo juiz" (arts. 686, $\S 2$ ? , e 705, II)?

Imaginem-se as comarcas grandes, de intenso movimento forense. Se se exigir a presença do juiz nos leilões, grande parte de seu expediente será tomado por essa atividade (com prejuízo para os demais atos judiciais), e as licitações terão de sujeitar-se à existência de vaga na pauta das audiências, somando-se ainda as dificuldades de sua locomoção para os diversos lugares em que possam estar os bens ou que possam ter sido designados para o ato.

E significativa, também, além da alteração sofrida pela disposição contida no art. 965 do Código de 1939 (abolindo-se a menção à "presença do juiz"), a referente ao auto de arremata- 
ção. $O$ art. 975 desse diploma dizia apenas: “A arrematação será reduzida a auto, que o juiz, o escrivão, o arrematante e o porteiro assinarão". E FREDERICO MARQUES, a respeito, escrevia, como já vimos: "A assinatura do auto deve ocorrer tão logo se encerre a arrematação, pois o juiz, o escrivão e o porteiro devem estar presentes ao ato, consoante determina o art. 965. E também o arrematante, como é óbvio". 45 Enquanto isso, de acordo com o Código de 1973, o auto - que é extensivo ao leilão (arts. 693, 694, caput, e 707) - , a ser assinado "pelo juiz, pelo escrivão, pelo arrematante e pelo porteiro ou pelo leiloeiro" (art. 694), só será lavrado "vinte e quatro (24) horas depois de realizada a praça ou o leilão" (art. 693).

É verdade que esse intervalo, de vinte e quatro horas, se destina também a propiciar a remição de bens (art. 788, 1$) ;^{46}$ mas demonstra não ser necessária a presença do juiz ao ato de arrematação, como ocorria ao tempo do Código anterior, em que "o auto devia ser lavrado logo após a última arrematação e antes de encerrada a praça", no dizer de AMÍLCAR DE CASTRO, coincidente com o de FREDERICO MARQUES, acima transcrito. ${ }^{47}$

4. Concordamos inteiramente com PONTES DE MIRANDA, em que "toda arrematação é ato do juiz, pelo menos no seu impulso (mandado de alienação)". ${ }^{48} \mathrm{E}$, aliás, o que já dizia a Ordenação: “. . . . A qual arrematação se fará sempre por mandado do Julgador, que mandou fazer a penhora e execução". ${ }^{49}$ Mas é exatamente nesse sentido que pensamos se deva entender a arrematação como "ato do juiz": "no seu impulso (mandado de alienação)" - não na sua realização material; nem mesmo no sentido de ser por ele presidida, ou de exigir-se sua presença ao ato.

Como já temos dito, parece-nos que os autores, que chegaram a mencionar a presença do juiz como obrigatória no ato de licitação, não tiveram na devida conta a importante alteração da sistemática processual respectiva. $O$ art. 965, caput, do Código anțigo estatuía: "A arrematação far-se-á em dia, hora e lugar anunciados, com a presença do juiz, do escrivão e do porteiro, expostos, se possível, os objetos que deverão ser arrematados". Enquanto isso, o Código de 1973 diz apenas: "A praça realizarse-á no átrio do edifício do fórum; o leilão, onde estiverem os bens, ou no lugar designado pelo juiz" (art. 686, § 2? ).

É evidente que foi intencional a omissão do legislador quanto à presença do juiz, tanto assim que no art. 694, caput, ao contrário, repetiu a exigência, que já constava do art. 975 
do Código de 1939, da assinatura do auto de arrematação "pelo juiz".

E foi acertada essa orientação do legislador do Código de 1973. "A praça realizar-se-á no átrio do edifício do fórum; o leilão, onde estiverem os bens, ou no lugar designado pelo juiz" (art. 686, § 20.). O leião é de bens móveis (artigo 704), a praça de imóveis (art. 697). O primeiro realiza-se evidentemente sem a presença do juiz, "onde se encontrem os bens, ou no lugar designado pelo juiz" (arts. 686, § $2^{\circ}$., e 705, II), pois "cumpre ao leiloeiro" (art. 705): ". . . II - realizar o leilão onde se encontrem os bens, ou no lugar designado pelo juiz; . . . . V - receber e depositar, dentro em vinte e quatro horas, à ordem do juízo, o produto da alienação; VI - prestar contas nas quarenta e oito horas subseqüentes ao depósito".

Por outro lado, a omissão da exigência da presença do juiz (que constava expressamente do Código anterior), aliada ao fato de a praça realizar-se no átrio do edifício do fórum, leva também, a nosso ver, à inequívoca conclusão de que ela também se faz sem a presença do juiz, "realizada" pelo porteiro dos auditórios (cf. art. 694), assim como o leilão é "realizado" pelo leiloeiro (art. 705, II, cit.).

O Código de Processo Civil português, tal como o Código brasileiro de 1939, é expresso em dizer, no art. 897, sob a rubrica "formalismo da arrematação", que esta "é presidida pelo juiz, que mandará anunciar a abertura da praça" (nO. 1); mas não diz que ela se faz "no átrio do edifício do fórum", como a atual lei brasileira, mas apenas que (art. 896): “1. A arrematação dos imóveis faz-se sempre no tribunal da situação; a dos móveis, ou no tribunal do lugar onde se encontrem ou noutro que seja julgado mais conveniente por acordo expresso do executado e dos credores ou por determinação judicial".

A presença do juiz no ato da arrematação se justifica se esta se fizer em audiência, na sala destinada a esse ato solene. Esse é o local em que o juiz ouve as partes e terceiros (testemunhas, peritos etc.), tomando lugar em seu assento próprio. Já no átrio não há lugar próprio para o juiz; átrio é, segundo a acepção mais comum, "grande sala central, de distribuição da circulação, num edifício; vestíbulo". ${ }^{50}$ No átrio não costuma haver cadeiras, muito menos cadeira curul. E não é próprio da função do juiz - sem que se queira ver nisso qualquer idéia de superioridade sobre as outras pessoas - o ficar de pé, durante os atos solenes do Juízo. Costuma-se dizer que o Ministério Público é a "magistratura de pé", para contrapô-la aos componentes do 
Poder Judiciário, que seriam a "magistratura sentada". Notou-o, com a magistral perspicácia, CALAMANDREI, ao fazer o paralelo entre o juiz e o advogado, no clássico Elogio dei giudici: "Esta diferença de funções, que se nota no decorrer do processo entre juiz e advogado - o primeiro: momento estático, e o segundo: momento dinâmico da justiça - persiste nas manifestações exteriores e nos sinais visíveis das audiências: o juiz está sentado, o advogado de pé; o juiz apóia a cabeça nas mãos, imóvel e recolhido, o advogado - de braços estendidos como tentáculos - é agressivo e nunca está quieto. . . ..."51

Não somente em seu gabinete o juiz despacha sentado, mas é nessa posição que se apresenta em todos os atos solenes de que participa. Pode-se dizer que o único ato que o juiz pratica de pé, quando necessário, é a inspeção judicial - o que se justifica pela próprio natureza da diligência, em que pode, quando seja preciso, ir "ao local, onde se encontre a pessoa ou coisa" (Cód. de Proc. Civil, arts. 440-3).

Se o Código quisesse a presença do juiz no ato da arrematação teria determinado que ela se fizesse em audiência; como fez o Código italiano, art. 581, ao dispor, quanto aos bens imóveis, que "o leilão tem lugar perante o juiz da execução, na sala das audiências públicas", 52 e o Código alemão, segundo o qual, também para os bens imóveis, "a hasta pública se realiza na audiência respectiva", como informa LEO ROSENBERG; ${ }^{53}$ e ainda o Código francês, de acordo com o qual (art. 704) ela "tem lugar na audiência das penhoras imobiliárias perante o tribunal" - devendo notar-se que "as ofertas" (lanços) "são feitas por intermédio de advogado".

O legislador brasileiro, entretanto, teve em vista, certamente, facilitar a realização das praças ou leilões, atendendo à realidade de que, não havendo leiloeiros oficiais na maioria das comarcas do País, mesmo os leilões continuariam, até que fossem providos esses cargos, a ser realizados pelos porteiros dos auditórios - como estava previsto, aliás, no Código de 1939, art. 972 (abstraindo-se, aqui, a diferente sistemática quanto à praça e ao leilão, em relação ao Código atual): “Se os bens não forem arrematados, serão vendidos em leilão público, por leiloeiro público, onde houver, à escolha das partes, ou pelo porteiro dos auditórios". Disposição essa que, para AMÍLCAR DE CASTRO, "continua em vigor. Se não houve reforma processual nesse ponto, como ensinam Planiol e Ripert, é preciso remontar ao direito anterior; há lugar para supor-se que as regras antigas foram implicitamente mantidas. É o que se chama: a autoridade da tradição. 
A lei antiga não cede enquanto não se descobre na lei em vigor um princípio novo em contradição com ela". 54

Assim, é grande o número de praças e leilões realizados nas comarcas de maior movimento forense; por isso não se determinou que eles se fizessem em audiência, presididos pelo juiz; efetuam-se "no átrio do edifício do fórum", ou "onde estiverem os bens, ou no lugar designado pelo juiz" (arts. 686, § 20., e 705, II). Imaginem-se comarcas como as de São Paulo e Rio de Janeiro. Mesmo em outras há dias em que se realizam, para uma única Vara, dois, três, quatro, cinco ou mais praças ou leilões, numa mesma tarde ou manhã. Nessas ocasiões, se o juiz tivesse de presidir efetivamente a todos eles, não faria outra coisa: não poderia realizar audiências nem despachar em seu gabinete, pois teria de deslocar-se continuamente ao átrio para presidir à licitação. Quer dizer: as praças ou leilões teriam de subordinar-se (com evidente prejuízo para a tão reclamada celeridade processual) à existência de vaga na pauta das audiências.

Atento a essa realidade, portanto, é que, a nosso ver, o legislador não determinou que a licitação se fizesse em audiência; e (conseqüentemente) suprimiu a menção que o Código anterior fazia (art. 965, caput) à "presença do juiz". E' o fez em boa hora; do contrário estaria mantendo a farsa, vigorante ao tempo do Código derrogado, da licitação feita "com a presença do juiz"; a mesma farsa, aliás, em que consistia a "audiência de leitura de sentença". ${ }^{55}$ A praxe então vigente se refere PONTES DE MIRANDA, analisando o problema do auto de arrematação sem assinatura do juiz: ". . . . Mas, pergunta-se, se o juiz o assinar depois, sem ter havido pedido de declaração da inexistência, ou certidäo? A praxe, quebrado o principio da imediatidade, de se deixar ao juiz assinar depois os atos a que devera estar presente, ou próximo, leva a dificuldades imensas na solução de problemas como esse. ...." ${ }^{\prime 56}$

Ademais, é de perguntar-se: Se o leiloeiro pode realizar o leilão "onde se encontrem os bens, ou no lugar designado pelo juiz" (art. 705, II, e 686, § $2^{\circ}$.), sem a presença deste, portanto, e prestando-lhe contas após (art. 705, V e VI) - por que não pode o porteiro, que exerce idêntica função, realizar a praça, nas mesmas condições? Ainda mais que normalmente o juiz poderá estar próximo (praxe já observada ao tempo do Código de 1939, que exigia a "presença" do juiz, como anotado por PONTES DE MIRANDA, na passagem acima), para atender a qualquer reclamação, ou para dirimir alguma dúvida surgida durante a licitação, que the seja levada pelos licitantes, pelas partes ou pelo próprio 
porteiro. $E$, de qualquer maneira, ainda que não haja essa proximidade do juiz (apenas recomendável, mas não exigida pelo Código) no momento da realização da hasta pública, qualquer reclamação quanto a alguma irregularidade praticada pelo porteiro Ihe poderá ser levada ao conhecimento até a assinatura do auto de arrematação, que é assinado apenas vinte e quatro horas depois (art. 693).

Não merecerá o porteiro dos auditórios, auxiliar da justiça, a mesma confiança que se tributa ao leiloeiro? Aquela função é desempenhada, na maioria das comarcas, por um oficial de justiça designado, não estando o porteiro mencionado entre os "auxiliares da justiça" nos arts. 139 a 144 do Código de Processo Civil, embora o esteja no art. 694, como já referido. No Paraná, por exemplo, apenas na Comarca da Capital é que existem dois cargos de Porteiro de Auditórios (Código de Organização e Divisão Judiciárias, Lei 7.297, de 8.1.80, art. 235, I, letra $g$ ); nas demais comarcas, "aos Oficiais de Justiça" é que incumbe (art. 167, IV) "exercer, onde não houver, as funções de Porteiro de Auditório, mediante designação do Juiz". Ora, assim sendo, não apenas os leiloeiros públicos, nomeados, têm fé pública quanto às certidões que expedirem relativamente às vendas, extraídas de seus livros em forma regular (Decreto 21.981, de 19.10.1932, art. 35; Lei 4.021, de 20.12.1961, art. 16); mas, evidentemente, também os porteiros dos auditórios, a quem incumbe, de acordo ainda com o Código de Organização Judiciária do Paraná, art. 168: “. . . . II apregoar os bens, nas praças e leilões judiciais; III - passar certidões de pregões, editais, praças, arrematações ou de qualquer outros atos que praticarem". Essa fé pública, que prevalece até prova em contrário, é, de resto, inerente ao exercício de sua função, já tendo sido declarada pelo Supremo Tribunal Federal, recentemente, quanto ao oficial de justiça (que faz as vezes do porteiro, na hipótese de que se trata): "O oficial de justiça tem fé pública, de sorte que sua certidão deve prevalecer até prova em contrário. ... ." 57

5. O Código de Processo Civil de 1973, por conseguinte, não exigiu (como fazia o Código de 1939) a presença do juiz no ato de realização da hasta pública; esta é atribuição do porteiro de auditório (como é atribuição do leiloeiro, onde houver, com relação aos bens móveis).

Mais um indício disso está no art. 688 , em que se prevê sanção apenas para "o escrivão, o porteiro ou o leiloeiro, que culposamente der causa à transferência"; com relação ao juiz não se previu sequer a responsabilidade "pelas despesas da nova pu- 
blicação", em que incorrem cumulativamente com a pena de suspensão esses auxiliares da justiça. E, no entanto, em outras disposições o Código cuidou de sanções e responsabilidade a que se sujeita o juiz, como se vê dos arts. 133 e 198, este específico para a hipótese de que trata; como específico seria o art. 688 na referência também ao juiz, se sua presença fosse efetivamente requisito para a realização da hasta pública.

BARBOSA MOREIRA não faz (como não faz o Código) absolutamente nenhuma referência à presença do juiz no ato da licitação, dizendo apenas: "Deve a licitação realizar-se em dia útil, no horário do expediente forense", 58 é, aliás, o que diz o Código (art. 686, IV e $\S 20$.). E a respeito do art. 688, acima aludido, comenta, tão-somente: "É óbvio, porém, que tal publicação se impõe em qualquer caso, haja ou não ocorrido 'motivo justo' para a transferência. A falta de justificação pode ser relevante para a incidência do parágrafo único, onde se faz responsável pelas despesas da nova publicação o escrivão, o porteiro ou o leiloeiro que culposamente houver dado causa ao adiamento, facultando-se ainda ao juiz, à vista das circunstâncias, aplicar-lhe a penalidade de suspensão por cinco a trinta dias". ${ }^{59}$ Nenhuma referência, também aqui, à ausência (e conseqüente responsabilidade) do juiz. Finalmente, ao tratar do "vício de nulidade", como causa de desfazimento da arrematação (art. 694, 1), ainda uma vez não faz menção de presença do juiz ao ato (que não deveria ser esquecida, por sua relevância, se exigida pelo Código), escrevendo: "Os motivos concebíveis são inúmeros: inobservância dos requisitos de publicidade (art. 687 e $\&$ \& 10. e 20.), falta de intimação do executado (art. 687, \& 30.$)$, impedimento do arrematante para licitar (art. 690, \& 10., 2 . parte), etc. ". ${ }^{60}$

Nem se diga que, exigindo o art. 694 que o auto de arrematação seja assinado também pelo juiz, estaria aí subentendida a exigência de que estivesse presente ao ato de arrematação mesmo. Tal conclusão não tem razão de ser, porque: a) o Código de 1939 havia sido expresso nos dois dispositivos a respeito do assunto (arts. 965 e 975, já citados), enquanto o Código atual (intencionalmente, a nosso ver) só o foi quanto à assinatura do auto (art. 694); b) o auto de arrematação só "será lavrado vinte e quatro (24) horas depois de realizada a praça ou a leilão" (art. 693).

Aliás, o que dá a certeza mais plena de que o respectivo auto é assinado pelo juiz independentemente de sua presença no ato anterior, de arrematação, é o fato de que no caso do leilão que, como visto, é indubitavelmente realizado pelo leiloeiro sem a presença do juiz (art. 705, II, V e VI) - , "efetuado o leilão, 
lavrar-se-á o auto, expedindo-se a carta de arrematação", nos termos do art. 707 do Código de Processo Civil; que está em harmonia, aliás, com os referidos arts. 694 (". . . . ou pelo leiloeiro ... .") e 693 (“. . . . que será lavrado vinte e quatro (24) horas depois de realizada a praça ou o leilão").

E nenhuma crítica merece o sistema instituído pelo Código: nesse prazo de vinte e quatro horas qualquer interessado poderá reclamar ao juiz contra qualquer irregularidade verificada na praça ou no leilão, assim como o juiz poderá constatá-la de of ício, antes de assinar o respectivo auto. ${ }^{61}$ 


\section{NOTAS}

1. Ed. de 1906, Garnier, Rio de Janeiro, "acomodadas ao foro do Brasil" por TEIXEIRA DE FREITAS, § CCCCXVII, pág. 339.

2. Cf., infra, $\mathrm{n}^{\circ} .3$, nt. 39 (com transcrição integral do $\S 27$, cit.).

3. V. no n⿳. 2 , nota 9 , e n ${ }^{\circ}$. 4 , infra, a transcrição desses dois artigos.

4. Novo Dicionário da Língua Portuguesa, de AURÉLIO BUARQUE DE HOLANDA FERREIRA, 1 ạ ed., Rio de Janeiro.

5. Comentários ao Código de Processo Civil, $1^{\mathrm{a}}$. ed., 1974, no ${ }^{\mathrm{O}}$. $389-93$ (págs. 28890), 398-402 (págs. 292-4), 424 (pág. 314), 425-6 (pág. 315), 427-41 (págs. 31621), 446 (pág. 324) e 467-8 (pág. 342).

No comentário ao art. 488, esse Autor fala apenas em responsabilidade também do juiz "pelo adiamento da praça", embora a ele não tenha se referido o mesmo artigo ( $\mathrm{n}^{\circ}$. 401, págs. 293-4), sem chegar a dizer, entretanto, que tal responsabilidade decorreria de sua ausência do local da licitação. Por outro lado, é de observar-se que o Código prevê a hipótese de não se realizar "a praça ou o lẹilão", e só alude à responsabilidade do escrivão, do porteiro ou do leiloeiro, "que culposamente der causa à transferência"; e que o saudoso Comentarista, a nosso ver, não fez perfeita exegese da sistemática do Código de 1973 (alterando a de 1939) no tocante à existência de duas praças e dois leilões: os primeiros com observância da "importância da avaliação", e os segundos sem tal limitação (ao invés de praça no primeiro caso e leilão no segundo; cf. artigos 686 , IV e VI; 687 , § $3^{\circ}$.; 688 , caput; $691 ; 692$, com a redação da Lei $6851 / 80 ; 697 ; 704)$. Assim é que entendeu que "há duas espécies de leilão: o que se faz pelo oficial de justiça, porteiro do auditório, quando os bens não encontram em praça oferta superior ao preço da avaliação (art. 686); e o que se realiza por leiloeiro público (arts. 704 a 707). É o que o artigo 697 não admite é que sejam os imóveis alienados por leiloeiro público. Confrontem-se os $\S \S 1^{\circ}$. e $4^{\circ}$. do art. 701" (ob. cit., nº. 446, pág. 324). Cf. sobre este problema JOSÉ AFONSO DA SILVA, Execução Fiscal, 1975, pág. 107 $\left(\mathrm{n}^{\circ} .18\right.$ e nota 103$) ; \mathrm{e}$, infra, notas 14,15 e 16.

Observe-se ainda que, no comentário ao art. 693, referente à lavratura do auto,o mesmo Autor distinguiu as duas situações: "Pelo direito anterior, o auto devia ser lavrado logo após a última arrematação e antes de encerrada a praça, isto é, antes de dar o juiz por encerrados os trabalhos da praça. / Pelo direito atual, o auto de arremataçãc deve ser lavrado vinte e quatro horas depois de realizada a praça, ou o leilão, isto porque o direito de remir deve ser exercido nesse prazo, antes da assinatura do mesmo auto (art. 788)" (ob. cit., no ${ }^{0}$ 426, pág. 315). Cf., infra, nota 12.

6. Comentários ao Código de Processo Civil, $1^{\mathrm{a}}$. ed., 1978, $\mathrm{n}^{\circ}$ s. $360-3$ (págs. 459-65), 365 (págs. 468-9), 373 (págs. 478-80), 374-6 (págs. 480-4), 385 (págs. 491-2), 394-7 (págs. 504-6).

7. Processo de Execução, 1975, págs. 156-69. Também aqui a confusão entre segunda praça e leilão; cf. págs. 158 ( $\left.\mathrm{n}^{\circ} .4\right), 163\left(\mathrm{n}^{\circ} .11\right), 167-8\left(\mathrm{n}^{\circ} .17\right)$.

8. Verbete "Arrematação", no Digesto de Processo, $1^{\text {a }}$. ed., Forense, 1/495-512, especialmente $n^{\circ} .3$, págs. $495-7$.

9. "A arrematação far-se-á em dia, hora e lugar anunciados, com a presença do juiz, do escrivão e do porteiro, exposto, se 'possível, os objetos que deverão ser arrematados".

10. Instituiçōes de Direito Processual Civil, vol. V, $2^{\mathrm{a}}$. ed., 1963, nº 1.210 , pág. 252 (grifo nosso).

11. Ibidem, $\mathrm{n} \circ$. 1.212 , pág. 254 , acrescentando, em nota: “ 'A arrematação deve ser feita por ordem do juiz' (LEITE VELHO, Monografia Juridica e Prática das Execuçōes de Sentenças, 1885, art. 193). Por isso mesmo, 'sem ordem do juiz, nem o escrivāo, nem o porteiro, podem fazer entrega do ramo" (RAMALHO, ob. cit., $\$ 392$, nota a)" (nota 134 ).

12. Ihidem, $\mathrm{n}^{0}$. 1.213, pág. 256. Cf., supra, nota 5, terceiro parágrafo.

13. J. F.. MARQLES, Manual, cit., vol. IV, $1^{\mathrm{a}}$. ed., 1976, nº 881 , pág. 187. 
14. Idem, ibidem, $\mathrm{n}^{0} .886$, pág. 191. Cf., supra, nota 5 , segundo parágrafo.

15. Comentários ao Código de Processo Civil, $1^{\text {a }}$. ed., no ${ }^{\circ} .50$, pág. 101. Também nesse Autor deparamos, inicialmente, com a confusão entre a segunda praça e o leilão: "Um elemento distingue, desde logo, segundo a disciplina do Código, a praça do leilão. Naquela, há lance mínimo predeterminado pela avaliação; neste, entrega-se o bem ao licitante que mais der" (comentário ao art. 686, n० . 48, págs. 98-9). Mas, adiante, verifica-se que essa observação está em contradição com o comentário feito ao art. 704: "Altera-se, assim, a disciplina anterior que admitia o leilão para quaisquer bens, subordinando-o, tão-somente à inexistência de licitante para a arrematação" (n ${ }^{\circ} .66$, pág. 129). Cf., supra, nota 5 , segundo parágrafo.

16. Cf. Execução Fiscal, cit., págs. $106-9$ (n ${ }^{\circ}$ s. $17-8$ e nota 103). Cf., supra, nota 5, segundo parágrafo.

17. Ibidem, pág. 105 (nº 16) (grifo nosso).

18. Ib., pág. $106\left(\mathrm{n}^{0} .17\right)$.

19. Sistemática do Novo Processo de Execução, 1978, no. 78, página 399.

20. Ibidem, págs. 405-6.

21. $I b ., \mathrm{n}^{\circ} .79$, pág. 421 . Ainda aqui a aludida confusão entre a segunda praça e o leilão, ao falar esse Autor em praça "de coisas móveis" (nº 78, pág. 396), e, depois, que a alienação de imóvel "só se processará em praça o que significará a apontada garantia de um preço mínimo quando da sua transferência: o preço da avaliação" (nº. 79, pág. 411) - apesar de suas próprias considerações feitas adiante (no. 79, págs. 418-9). Na verdade, no sistema do Código vigente, só se faz praça de imóvel; e este, na segunda praça (e não em leilão), pode ser alienado por valor abaixo do da avaliação, "a quem mais der" (art. 686, VI), com recusa apenas do "preço vil" (art. 692, segunda parte, na redação da Lei 6.851, de 17.11.80).

22. Tratado das Execuções - Processo de Execução, 1975, nº. 627, 11/512-3.

23. Tanto assim que nesse passo o Autor só fala na praça e no porteiro dos auditórios, não falando no leilão nem no leiloeiro; e - o que é ainda mais significativo - alude a "praça de bens móveis" (ibidem, nos. 627-8, 11/512-3; grifo nosso) . . . em contradição com tópico subseqüente, referido especificamente aos arts. 704 e 707 do Código de 1973 ( $\left.i b ., \mathrm{n}^{\circ} .661,11 / 522\right)$. E adiante, ao falar a respeito das particularidades sobre a "venda de bens de incapazes" (ib., n'. 634, 11/514), fala em bens em geral, não as restringindo ao "imóvel de incapaz", como faz o Código atual, art. 701; e em contradição, aqui também, com sua própria anotação posterior, em que faz tal restrição (ib., $\left.\mathrm{n}^{\circ} .651,11 / 518\right)$.

24. J. S. PACHECO, Tratado, cit., n' ${ }^{\circ}$ s. 658 e $660,11 / 520$ e 521.

25. Fazendo corretamente a distinção: praça para os bens imóveis e leilão para os móveis (Primeiras Linhas de Direito Processual Civil, vol. III, 33a. ed., 1979, nº. 928, págs. 311-2).

26. Ibidem. págs. 312-3. Oportuna, aqui, a observação: "Quando nessa" (comarca) "não houver leiloeiro público, não vemos outra solução senão, apoiado no direito tradicional, conferirem-se suas atribuições ao porteiro dos auditórios (AMÍLCAR DE CASTRO). Embora o leiloeiro não seja serventuário da justiça, mas mero agen"te comercial, exerce no leilão judicial missão do Estado e nessa qualidade cumpre suas funções" (ib., página 313, grifo nosso; cif., infra, $\mathrm{n}^{0} .4$, nt. 54 ).

27. (ib., nº. 929 , pág. 313 (grifos nossos)

28. (ib., nº. 931, pág. 319 .

29. Comentários ao Código de Processo Civil, tomo XI, $1^{\text {a }}$. ed., 1976, pág. 184.

30. Cf. Comentários ao Código de Processo Civil, tomo XIV, 2a ${ }^{\mathrm{a}}$ ed., 1961, pág. 167.

31. Comentários, cit., tomo X, $1^{\mathrm{a}}$. ed., 1976, pág. 371 (grifos nossos).

32. Apenas com referência ao art. 688 , parágrafo único, em lugar do art. 966 , e com exclusão da referência ao "Código Penal, art. 358".

33. "Serão passíveis de pena disciplinar e multa de duzentos a quinhentos cruzeiros além de condenados nas respectivas custas, os serventuários ou depositários que não comparecerem ou não comunicarem oportunamente o seu impedimento, concorrendo, assim, para a transferência da praça".

34. Cf. PONTES DE MIRANDA, Comentários, cit., tomo XIII, 2ª ed., 1961, pág. 363. 
35. PONTES DE MIRANDA, Comentários (ao CPC/1973), cit., tomo X, págs. 38891.

36. Ibidem, pág. 420 (grifo nosso).

37. Ib., ib. (grifo nosso).

38. Ib.; pág. 421 (grifos nossos).

39. A referência deve ser ao $\S 27$ (e não 17) do Título 86, Livro III, das Ordenações: "E passado o termo dos pregões, não será necessário ser o condenado mais requerido, para dizer se tem embargos à arrematação; porque o requerimento, que lhe foi feito, que pagasse, ou desse penhora, basta. Mas passado o tempo dos pregões, os bens, em que for feita penhora, se arrematarão, e venderão a quem por eles mais der. A qual arrematação se fará sempre por mandado do Julgador, que mandou fazer a penhora e execução. E fazendo-se a execução em bens de raiz, será para ela requerida a mulher do condenado, se for casado". Cf., supra, no ${ }^{0}$, nt. 2.

40. Comentários (ao CPC/1973), cit., tomo X, págs. 345-6.

41. Cf. Comentários, cit., tomo XIII, pág. 339 (grifo nosso).

42. No mesmo sentido, aliás, a recente Lei 6.851 , de 17 de novembro de 1980 (que alterou também os arts. 687 e 692), dando nova redação ao art. 700, dispõs que "poderá o juiz, ouvidas as partes e sem prejuízo da expedição dos editais, atribuir a corretor de imóveis inscrito na entidade oficial da classe a intermediação na alienação do imóvel penhorado".

43. No regime do Código de 1939, como se sabe, em geral se entendia, com base nos. arts. 965 e 972, combinados, que havia a praça tanto de bens ịmóveis como de móveis, realizada pelo porteiro dos auditórios, observado o valor mínimo estimado na avaliação; e que havia o leilão, dos mesmos bens, realizado pelo leiloeiro (ou, eventualmente, pelo porteiro), sem observância daquele valor mínimo. Tal leilão correspondia ao que é hoje a segunda praça ou oo segundo leilão (cf. art. 692 do Código de 1973, na redação da Lei 6.851/80, que usa exatamente dessa expressão: “. . . . em segunda praça ou leilão ...."). Veja-se o tex to do art. 972, caput, daquele Código: "Se os bens não forem arrematados, serão vendidos em leilão público, por leiloeiro público, onde houver, à escolha das partes, ou pelo porteiro dos auditórios".

44. Observe-se que nessa execução não existem dois leilões, mas um único, realizado pelo leiloeiro (art. 23, $\S 2^{\circ}$.), em que os bens podem ser arrematados por valor inferior ao da avaliação. $\bar{E}$ o que deflui dos arts. 22,23 e 24 , conjugados, estabelecendo-se ainda, neste último, o direito preferencial de adjudicação pela Fazenda Pública: "I - antes do leilão, pelo preço da avaliação, se a execução não for embargada ou se rejeitados os embargos; II - findo o leilão: a) se não houver licitante. pelo preço da avaliação; b) havendo licitantes, com preferência, em igualdade de condições com a melhor oferta, no prazo de 30 (trinta) dias". No sistema do Código de Processo Civil não há tal preferência: a adjudicação ao credor só tem lugar "finda a praça sem lançador", e pelo valor da avaliação (art. 714, caput).

45. Cf., supra, $\mathrm{n}^{\circ} .2, \mathrm{nt} .12$.

46. Cf. AMILCAR DE CASTRO, trecho transcrito na nota 5, supra, terceiro parágrafo; CELSO NEVES, Comentérios, cit., $n^{\circ}$. 55, pág. 110; acórdão do Supremo Tribunal Federal, de 22 de junho de 1979, em que se citam essas duas lições (RE 91.053-RJ, 2a. Turma, rel. Min. DJACI FALCÃO; RTJ 94/386-93, especialmente pág. 392 ).

47. Assim, o auto de arrematação, hoje, equipara-se mais, sob esse aspecto, por exemplo, ao auto de partilha, que o juiz assina depois de ter sido ela "lançada nos autos" segundo o esboço anteriormente aprovado (arts. 1.024 e 1.025), do que, $v$. g., ao termo de audiência lavrado, este sim, no próprio transcorrer dela, realizada esta sim sob a presidência do juiz, como declara expressamente o Código, no art. +46 , além de demonstrá-lo em inúmeros outros artigos $(344,346,410,413$, $414,415,416,417,445,448,449,450,451,452,453,454,455,456,457)$. De igual forma, o Código é inequívoco quanto à realização da inspeção judicial pes- 
soalmente pelo juiz (arts. 440-2); e determina que, concluída a diligência, o juiz mandará lavrar auto circunstanciado, mencionando nele tudo quanto for útil ao julgamento da causa" (art. 443, caput).

48. Cf., supra, n 3 , nt. 40.

49. Cf., supra, n ${ }^{\circ} 3$, nt. 39.

50. Dicionário Aurélio, cit.

51. Eles, os Juizes Vistos por Nós, os Advogados, tradução portuguesa de Ary dos Santos, $4^{\mathrm{a}}$. ed., Lisboa, III, pág. 50.

52. Quanto aos bens móveis, dispõe o art. 532, primeiro parágrafo, do Código de Processo Civil italiano: "(Venda por meio de comissário) - Quando o considere oportuno, o pretor pode dispor que as coisas penhoradas sejam confiadas a um comissário, a fim de que proceda à venda"; e o art. 534, primeiro parágrafo: "(Venda em leiläo) - Quando a venda deve ser feita em leilão público, o pretor, com o provimento previsto no art. 530, estabelece o dia, a hora e o lugar em que deve realizar-se, e confia a realização ao secretário" (cancelliere), "ou ao oficial judiciário, ou a um instituto a isso autorizado".

E sobre essa "venda por meio de comissário" ("vendita a mezzo di commissionario"), observa SÉRGIO COSTA: "a venda aqui prevista é, em antítese à venda em leilão, uma venda por negociação privada" (a trattativa privata): "e ainda se o comissário vende o bem em leilão, isso se considera como um ato interno e privado dele comissário, que na realidade é somente obrigado a vender com observância das condições previstas no artigo 533. O comissário não poderá ser senão uma pessoa ou um instituto de confiança do pretor:ainda que não se trate de um comissário inscrito em registros (como os corretores de bolsa) ou autorizado expressamente (como o instituto de que trata o art. 159 das disposições de atuação), deverá trata-rse de um comissário qualificado (por exemplo, uma casa idônea de venda em hasta), que proporcione uma segura garantia de confiança" (Manuale di diritto processuale civile, $4^{\mathrm{a}}$. ed., Turim, 1973, nº 414 , pág. 549; grifos do original e nosso).

Observe-se ainda que, de acordo com o art. 168 das Disposições para a Atuação do Código de Processo Civil, "as reclamações contra a atuação do oficial encarregado de venda são propostas pelos interessados com requerimento ao pretor./O requerimento não suspende as operações de venda, salvo se o pretor, com decreto, determinar a suspensão. / Sobre o requerimento o pretor decide sem demora, com ordenança" (ordinanza) "irrecorrível, ouvidos o requerente e as partes". Por outro lado, de acordo com o art. 537, terceiro parágrafo, do Código de Processo Civil, "do leilão se redige ata" (processo verbale), "que se deposita imediatamente na secretaria"; e, nos termos do art. 169 das Disposições de Atuação, "o secretário da pretoria, junto ao qual é depositada a ata de venda, de acordo com o art. 537, último parágrafo, do Código, cuida do registro dela".

Tudo está a mostrar que, evidentemente, o juiz (pretor) não está presente à "venda", quer a efetuada "por meio de comissário" (CPC, art. 532), quer a efe tuada "cm leilão", por meio do secretário, oficial judiciário ou instituto autorizado (art. 534); e que o escrivão (secretário) não se faz presente na primeira modalidade de "venda" nem na segunda, quando esta é realizada pelo ofícial judiciário ou por instituto, devendo apenas receber e registrar a respectiva ata.

53. Tratado de Derecho Procesal Civil, trad. de Angela Romera Vera, B. Aires, 1955 (da $5^{\text {a. }}$. ed. alemã, de 1951), § 202, 1, III/223.

Quanto aos bens móveis, resume LEO ROSENBERG: "As demais coisas" (que não dinheiro) "se transformarão em dinheiro; normalmente, mediante subasta que realiza o executor ( $\S \S 814,816$ e ss.; veja-se infra, a), também os títulos (sobre is to $\S \S 822$ e 823); mas não as letras de câmbio nem outros documentos endossáveis sobre créditos (veja-se infra, §.193, II, 4 c); ou mediante venda livre, que se permite pelo valor do metal quando se trata de objetos de ouro e prata que se intentou subastar sem resultados ( $\$ 820$, inc. 2$)$, e que é conveniente para os títulos de bolsa ou mercado ao valor de câmbio do dia ( $\$ 821$ ); ou, em todos os casos, mediante qualquer outra forma de liquidação que ordene o tribunal da 
execução a pedido do credor ou do devedor ( $\$ 825$; veja-se infra, b)" (ibidem, $\S$ 191, 3, III/163; grifos do original e nossos).

(Os executores judiciais, que realizam a subasta (hasta pública), "são funcionários independentes encarregados das notificações e execuções" (idem, ib., § 26, I/139); e os parágrafos citados no tex to são do Código de Processo Civil alemão - Zivilprozessordnung.)

Adiante, explica: “a) A subasta está regulada minuciosamente. Realiza-se publicamente pelo executor ( $\S 814$ ), não antes de transcorrida uma semana desde a penhora $(\S 816, \mathrm{I})$; celebrar-se-á na municipalidade do lugar de penhora (§816, II), depois de anunciar-se publicamente o momento, lugar e objetos da subasta ( $\S 816$, III). Credor e devedor podem convencionar forma diferente $(\$ 816, I I, I I I)$, ou ordená-la o tribunal da execução em cujo distrito se realiza a subasta (§ 825; OLG, Munique, BayZ, 1933, 260v). ...." "b) Podem considerar-se como outras classes de realização ( $(825)$ : a venda ou subasta por um técnico (p. ex., de uma obra de arte); a venda livre pelo executor, que realiza o contrato de acordo com o BGB, $\S \S 929$ e ss.; . . ." (id, ib., § 191, 3, III/164 e 165; grifos do original e nossos).

54. Comentários, cit., no. 463 , pág. 339. "Continua em vigor" - entenda-se - apenas na parte final (". . . . ou pelo porteiro dos auditórios"), e para a hipótese de não haver leiloeiro na comarca; não no restante do artigo, em contradição com o sistema atual (inclusive quanto à escolha do leiloeiro livremente "pelo credor" - art. 706, CPC/1973). Cf., supra, nº. 2, nt. 26.

55. C. MONIZ DE ARAGÃO, Comentários ao Código de Processo Civil, $3^{\mathrm{a}}$. ed., $1979, n^{\circ} .335$, pág. 325 .

56. Comentários, cit. (ao CPC/1973), art. 694, tomo X, pág. 385.

57. RI: $85.598-\mathrm{RJ}$, em $31.8 .76,1^{\mathrm{a}}$. Turma, rel. Min. CUNHA PEIXOOTO, RT 500/ 262.

58. O Novo Processo Civil Brasileiro, vol. II, 1a a ed., 1976, pág. 91; cf. $5^{\text {a }}$. ed., 1982, pág. 338.

59. Ibidem, $1^{\mathrm{a}}$. ed., $\mathrm{\amalg} / 88 ; 5^{\mathrm{a}}$. ed., pág. 335 .

60. $I b, 1^{\mathrm{a}}$. ed., II/96; $5^{\mathrm{a}}$. ed., pág. 342 .

61. O entendimento aqui sustentado, adotado anteriormente em sentença que julgou improcedentes embargos à arrematação em que se alegava a nulidade da praça realizada, pela ausência do juiz do átrio do edifício do fórum (e que deu origem a este trabalho), foi acolhido integralmente em acórdão de 17 de março de 1981, do Tribunal de Alçada do Paraná, com a seguinte ementa, na parte que ora interessa: "HASTA PÚBLICA - As praças e leilões ao contrário do que dispunha o Código de 1939, não șe processam em audiência, mas, efetuam-se no átrio do edifício do fórum, onde estiverem os bens, ou no lugar designado pelo juiz, realizados e apregoados pelo oficial porteiro ou leiloeiro, quando se trata, respectivamente, de bens imóveis ou móveis. Arts. 686, § $2^{\circ}$. e 705 , II, do C. P. Givil". No corpo do aresto, quanto à matéria $\mathrm{em}$ causa, lê-se: "Também improcede a arg üção de nulidade da praça pela falta do juiz processante, dirigente do feito, durante a realização da venda, pela ausência do átrio./As praças e leilões, pelo Código de Processo Civil em vigor, ao contrário do que dispunha o Código anterior, não se processam em audiência, sob presidência do juiz da execução, mas, efetuam-se no átrio do edifício do fórum. onde estiverem os bens, ou no lugar designado pelo juiz (arts. 686 , $2^{\circ}$., e 705 , Ш)./'O leiloeiro não é um serventuário da Justiça, ministra HLMBERTO THEODORO JÚNIOR, mas um agente comercial autônomo chamado a prestar colaboração à a tividade judicial, na diligência de conversão dos bens móveis penhorados em dinheiro. Embora agente autônomo, o ato que pratica é ato judicial por delegação do juiz da execução, consubstanciando, por isso mesmo, ato de alienação judicial. O edital do leilão, portanto é expedido pelo ju ízo e apenas publicado pelo leiloeiro. $O$ credor pode livremente escolher o leiloeiro, mas quem ordena a realização do leilão é o juiz' (in Comentários ao Código de Proces. so (ivil, volume 4. 1978, Forense, n! 395)./Já, quanto à praça de bens imóveis que se realiza no átrio do edifício do fórum é apregoada pelo oficial porteiro, auxiliar da justiça ou ierventuário da justiça./Cabe a ambos, leiloeiro ou oficial por- 
teiro de auditório, realizar o ato do leilão ou da praça, previamente determinado e designado pelo juiz da execução, apregoando-o./O auto de ocorrência (arrematação), sim, que resulta do leilão ou da praça, deverá ser assinado pelo juiz que verificará da obediência aos requisitos da venda judicial": (Acórdão n? 13.123, proferido na Apelação Cível n? 1.628/80, de Maringá, 2ạ Câmara Cível, relator o Juiz NEGI CALIXTO, presentes os Juízes Sydney Zappa (Presidente, sem voto), Osíris Fontoura e Franco de Carvalho). 